\title{
A Photometric Method for Recording Hoof Diseases in Cattle, with Special Reference to Haemorrhages of the Sole
}

By C. Bergsten

Experimental Station, Veterinary Institute, Swedish University of Agricultural Sciences, Skara, Sweden.

\begin{abstract}
Bergsten, C.: A photometric method for recording hoof diseases in cattle, with special reference to haemorrhages of the sole. Acta vet. scand. 1993, 34, 281-286. - After cleaning and trimming, the sole surface and interdigital space of the hooves of cows are photographed in a standardized way. The colour slides are projected on to a screen and the haemorrhages of the sole (reflecting Pododermatitis aseptica diffusa) and the lesions of Dermatitis interdigitalis and Erosio ungulae are scored according to their severity and extent by 2 people who do not know the identity of the cows. In a repeatability test the correlation coefficients between 2 assessments of the haemorrhages in the sole ranged between 0.78 and 0.88 for assessments of the front hooves, the hind hooves and all the hooves together.
\end{abstract}

foot diseases; laminitis; subclinical disease; lameness.

\section{Introduction}

In research aimed at identifying risk factors for hoof diseases the records of hoof disease have hitherto been obtained at a clinical examination and on the basis of the clinical signs or a visual inspection of the hooves (Smedegaard 1964, Peterse 1980, Andersson \& Lundström 1981, Manson \& Leaver 1988a, Philipot et al. 1990). Such observations are necessarily subjective to some degree, and even if good agreement can be obtained between different observers (Manson \& Leaver 1988a) it is always difficult to maintain consistent scoring of the severity of a disease over a period. In order to try to overcome this problem a standardized photometric method has been developed for evaluating disease information retrospectively. Results obtained by using this method have been reported (Bergsten et al. 1986, Bergsten 1988, 1992, Bergsten \& Pettersson 1992). The aim of this article is to describe the method in greater detail and to discuss its usefulness in comparison to other methods for recording hoof diseases.

\section{Materials and methods \\ Background}

The method is developed primarily to assess objectively the aetiological and pathogenetic significance of the factors which predispose cattle to laminitis (Pododermatitis aseptica diffusa), but can be used to record other hoof diseases as well (i.e. Erosio ungulae and Dermatitis interdigitalis).

Clinical laminitis can be acute, subacute or chronic. These different forms result in different types of disturbances to an animal's mobility (Nilsson 1963). Subclinical laminitis is very common (Peterse 1980, Andersson \& Lundström 1981) and manifests itself as abnormal- 


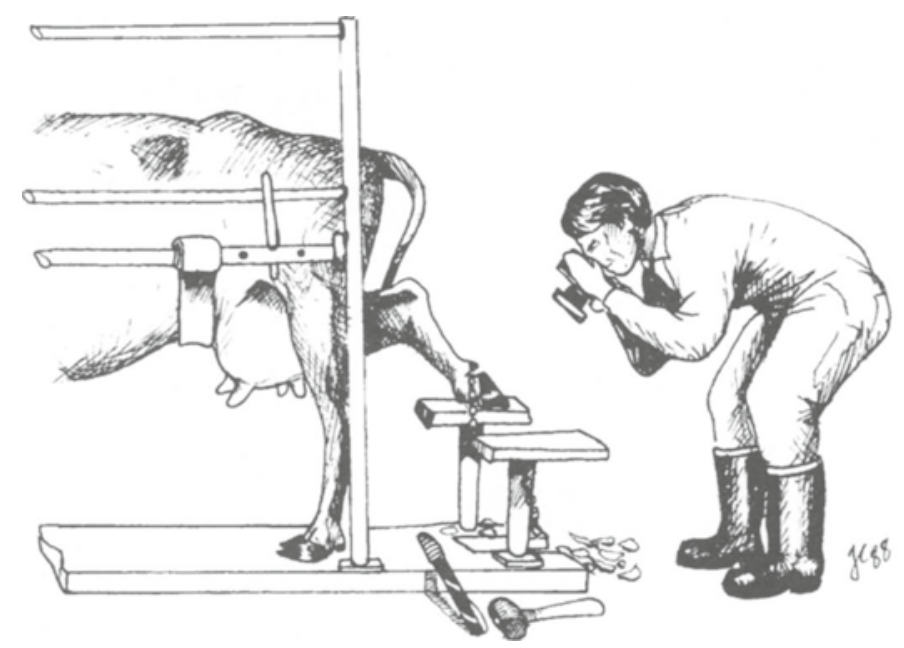

Figure 1. The surface of the sole is photographed after hoof trimming in a standardized way.

ities of the sole horn; these are due to inflammatory reactions in the corium as a result of which exudations of serum and, or, haemorrhages occur (Smedegaard 1964, Andersson \& Bergman 1980, Espinasse et al. 1984). As the hoof horn grows the haemorrhages gradually move down to the surface of the sole where they appear as discolorations (Peterse 1980, Greenough 1987). The interval between the occurrence of the haemorrhages and the appearance of the discoloration of the hoof when it is trimmed depends on the rate of growth of the sole horn and the thickness of the sole. The rate of growth of the horn of the hoof wall is approximately $5 \mathrm{~mm} / \mathrm{month}$ (Prentice 1973, Manson \& Leaver 1988b) and as a result, given a steady rate of growth of the sole horn and a sole thickness after trimming of about $10 \mathrm{~mm}$, the haemorrhages should appear in the sole surface from about 2 months after the initial injury.

Sole haemorrhages are most commonly found 2 to 3 months after calving and are more common in primiparous cows (Peterse 1980, Berg- sten et al. 1986, Greenough \& Vermunt 1991). They are usually located close to the palmar or plantar part of the hoof bone, but they sometimes occur in the apical area, or are scattered over the sole surface, or in the white line (Vermunt 1990). The clinical significance of the haemorrhages is supposed to be related to their extent and intensity (Peterse 1980, Espinasse et al. 1984)

\section{The phototechnique}

The cow is restrained in a trimming box and the foot to be examined is fixed in a raised position. The foot is cleaned thoroughly and the hoof functionally trimmed with a hammer and blade or a hoof grinder and hoof knife. The surface of the sole and the interdigital space is then photographed with a $50 \mathrm{~mm}$ lens and a ring flash, using a 50 ASA positive colour film. The camera should be held rigidly with the lens parallel to the surface of the sole of the hoof, at a distance of about $40 \mathrm{~cm}$, so that the 2 digits fill the field of view (Fig. 1 and 2). Each photograph is labelled with a code to 
identify the herd, the cow, and the foot being examined, without obscuring any part of the hoof, and so that the code can be obliterated when the photograph is being evaluated.

\section{Criteria for evaluation}

To evaluate the lesions the slides are projected on to a screen and examined at the same time by 2 people who does not know the identity of the cow. The 2 judges should agree the score.

For scoring the lesions due to Pododermatitis aseptica diffusa the severity and extent of the haemorrhages on each digit is evaluated on the basis of the following 6 point scale:

0 for a sole with no haemorrhages, 1 for a sole with slight haemorrhages in a small area, 2 for a sole with slight haemorrhages in a large area (Fig. 2, right) of the sole surface, or moderate haemorrhages in a small area, 3 for a sole with moderate haemorrhages in a large area, 4 for a sole with severe haemorrhages in a small area (Fig. 2, left), and 5 for a sole with severe haemorrhages in a large area or with a sole ulcer. Each digit should be scored separately and the total points are calculated for the front hooves, the hind hooves and all the hooves together (theoretical maximum points per cow 20, 20 and 40, respectively).

For scoring the lesions due to Erosio ungulae and Dermatitis interdigitalis a 4 point scale is preferred:

0 for no pathological signs, 1 for slight, 2 for moderate and 3 for severe pathological signs. The total points for Erosio ungulae are calculated for the front hooves, the hind hooves and all the hooves, as before (maximum points 12,12 and 24 respectively). For Dermatitis interdigitalis each interdigital space is scored and the total scores for the front hooves, hind hooves and all the hooves are calculated (maximum points 6,6 and 12 , respectively).

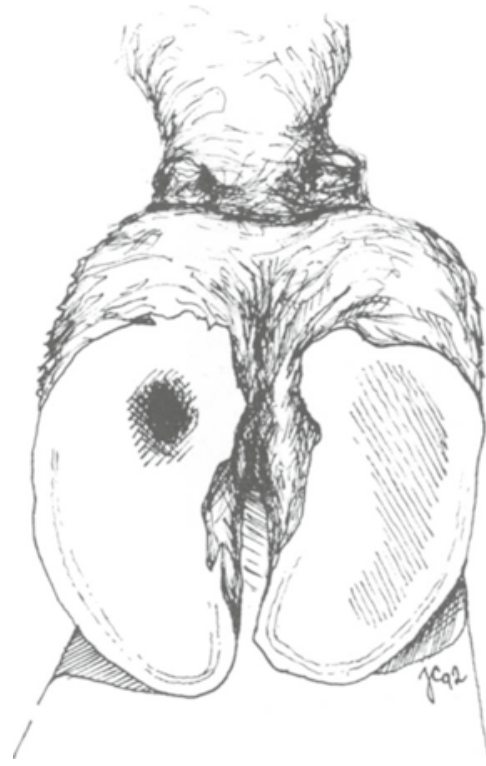

Figure 2. Right digit shows slight haemorrhages in a large area (scoring 2 points). Left digit shows severe haemorrhages in a small area (scoring 4 points).

\section{Repeatability}

The repeatability of the assessment for haemorrhages of the sole was determined in a blind test by re-examining 1400 slides, each showing the 2 digits of 1 foot from 350 cows. The slides had been evaluated 4 years previously (Bergsten 1988) and were examined in 1 day by the same 2 people who had examined them before. The slides were stored in darkness and at room temperature between the 2 evaluations. The results from each digit were summarized for front digits, hind digits and all digits and compared using both Spearman's and Pearson's correlation coefficients using the Proc corr procedure (SAS Institute Inc. 1987). Medians and 10th and 90th percentiles for differences between the first and second evaluation were calculated for each digit using the Proc Univariate procedure (SAS Institute Inc. 1987). 


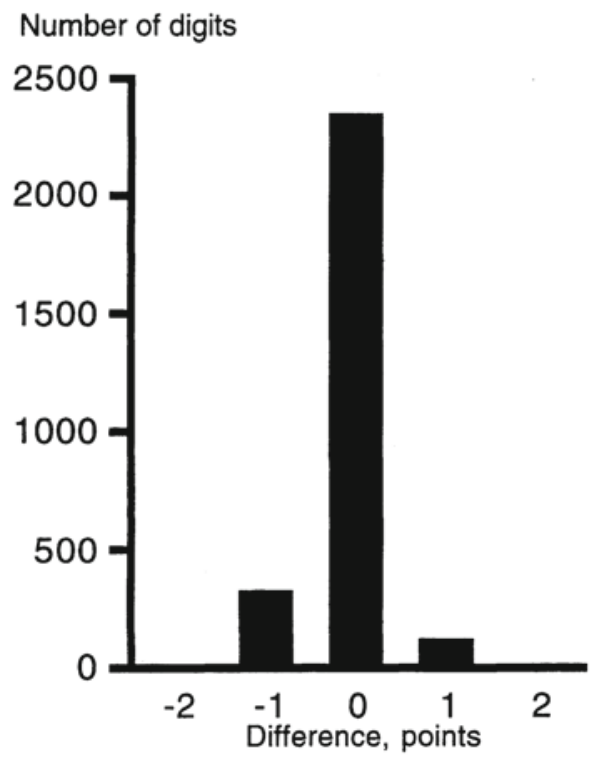

Figure 3. Difference between the first and second evaluation for all digits $(\mathrm{n}=2800)$.

\section{Results}

The repeatability test gave Spearman and Pearson correlation coefficients of 0.78 and 0.85 , respectively, for the front hooves, 0.85 and 0.88 for the hind hooves, and 0.86 and 0.88 for all the hooves $(\mathrm{p}<0.001)$. For all comparisons the median of the deviation for each digit between the 2 tests was 0 . The value for the 10 th percentile was also 0 for all the comparisons. The values for the 90th percentile were -1 for the right front inner claw and for all 4 claws of the hind hooves, and 0 for the other comparisons. The results are further illustrated in Fig. 3; 83.4\% of the 2 evaluations were equal, and $99.6 \%$ differed not more than 1 point.

\section{Discussion}

The standardization of clinical evaluation of hoof diseases by different people at different times is problematic. Several methods have been used to try to overcome this problem.
Thysen et al. (1981) used a specially trained person to record hoof diseases while cows were being routinely hoof-trimmed. Philipot et al. (1990) provided farmers with a coloured map of the hoof to help them to record Erosio ungulae and sole ulcers in a consistent way. Manson \& Merritt (1990) also provided farmers with a manual of illustrations describing the type, position and distribution of the lesions they were asked to record. Mills et al. (1986) prepared a special form on which the hoof capsule was divided into zones to help to standardize the clinical evaluation of the lesions.

A photographic record of a hoof makes it possible to evaluate any lesions more objectively than is possible during a farm visit or from a written report. Its advantages are that the photographic technique can easily be standardized so that anyone can make the record, and - particularly for experimental studies the photographs can be evaluated later by several independent observers who do not know the identity of the cow, and they can be evaluated as often as desired to assess the repeatability of the assessments.

However, the photographic method is not free of possible errors. One of them is the standardization of the hoof-trimming before the photograph is taken. It is essential that it is executed with care, that no lesions are induced by the trimming and that all the lesions exposed by the trimming are recorded. Trimming is itself a kind of treatment and can help to prevent further lesions from developing. In experimental studies it is therefore very important to ensure that all the animals are treated equally and at a time that is relevant to the aetiological factors being studied.

In the present investigation the repeatability test showed a highly significant correlation between the 2 assessments, although at the second assessment the haemorrhages were judged to have been slightly milder, particu- 
larly in the hind hooves. This discrepancy emphasises the importance of calibrating the point-scoring scales with great care for making comparisons on different occasions.

The scales proposed in this article have been used previously (Bergsten et al. 1986, Bergsten 1988, 1992, Bergsten \& Pettersson 1992) and appear to be appropriate for characterising the type and severity of hoof diseases. Experiences from these trials indicate, for example, that a score of 1 to 2 points per digit for Erosio ungulae will not generally be associated with clinical lameness, whereas a score of 3 will be associated with lameness. In contrast, most scores for Dermatitis interdigitalis indicate just a subclinical disease. The scale proposed to characterise haemorrhages in the sole is based on a combination of their severity and extent. Scores of 1 to 2 per digit may be interpreted as having been associated with subclinical laminitis, whereas scores of 3 to 5 is more likely to have been associated with acute or sub-acute clinical signs; many cows with such high scores may have signs of chronic laminitis or sole ulcers at registration (Weaver 1979).

The present scale used to characterise haemorrhages of the sole is similar to that used by Peterse (1980). In both scales the yellowish discoloration of the horn, which is probably associated with the diffusion of serum into the corium, is not considered to be a significant change. The scales are also comparable in that they both take account of the severity and extent of the haemorrhages; as an example a slight haemorrhage covering a large area will receive the same score as a moderate haemorrhage covering a small area. In such cases equal total points probably represent conditions with a similar pathogenesis, but not necessarily a similar clinical appearance. The same problem of interpretation arises when the total scores of individual cows are com- pared, because the total score cannot distinguish between a cow with one severely affected hoof and a cow with several mildly affected hooves (Enevoldsen \& Gröhn 1991). However, the risk of an incorrect interpretation is small because in most cases the haemorrhages appear on the corresponding digits of the right and left legs (Peterse 1978). Such problems of interpretation can also be reduced by using a scale which is adjusted to the clinical importance of the lesions, as proposed by Greenough and Vermunt (1991). These authors also used a photometric method and evaluated haemorrhages in 6 different zones of the soles of the hind hooves. This system might be advantageous if the aetiology and pathogenesis of the haemorrhages are different in the different zones.

The photometric technique described should make it possible to assess hoof diseases more objectively. It should be particularly valuable in studies of the aetiology and pathogenesis of those haemorrhages of the sole which characterise different degrees of laminitis. Sole ulcer is described as a serious complication to laminitis (Peterse 1980; Espinasse et al. 1984). Therefore, it was included and scored 5 in the scale of evaluation proposed in the present article. This might be questioned, since the aetiology and pathogensis to sole ulcers are disputable and probably multifactorial.

\section{Acknowledgement}

The investigation was supported by the Swedish Council for Forestry and Agricultural Research and by the Swedish Farmers' Foundation for Research.

\section{References}

Andersson L, Bergman A: Pathology of bovine laminitis especially as regards vascular lesions. Acta vet. scand. 1980, 21, 559-566.

Andersson L, Lundström $K$ : The influence of breed, age, body weight and season on digital diseases and hoof size in dairy cows. Zbl. Vet. Med. A, $1981,28,141-151$. 
Bergsten $C$ : Sole bruising as an indication of laminitis in cattle. A field study. Proc. 15th World Buiatrics Congress. Palma de Mallorca, Spain, 1988, 1072-1076.

Bergsten $C$ : Subclinical laminitis - studies on risk factors. Proc. VIIth Int. Symp. Disorders Ruminant Digit, Rebild, Danmark, 1992, in press.

Bergsten C. Andersson L, Wiktorsson H: Effect of feeding intensity at calving on the prevalence of subclinical laminitis. Proc. Vth Int. Symp. Disorders Ruminant Digit, Dublin, Ireland, 1986, 3386.

Bergsten C, Pettersson B: The cleanliness of cows in tied stalls and the health of their hooves as influenced by the use of electric trainers. Prev. vet. Med. 1992, 13, 229-238.

Enevoldsen C, Gröhn YT: Sole ulcers in dairy cattle: Associations with season, cow characteristics, disease, and production. J. Dairy Sci. 1991, 74, 1284-1298.

Espinasse J, Savey M, Thorley CM, Toussaint Raven $E$, Weaver $A D$ : Atlas en couleur des affections du pied des bovins et des ovins. (Colour atlas of disorders of cattle and sheep digits, international terminology). Editions du point Veterinaire. Maisons Alfort, France 1984.

Greenough PR: An illustrated compendium of bovine lameness. Part 1. Modern vet. Pract. 1987, 68, 6-9.

Greenough PR, Vermunt JJ: Evaluation of subclinical laminitis in a dairy herd and observations on associated nutritional and management factors. Vet. Rec. 1991, 128, 11-17.

Manson FJ, Leaver JD: The influence of concentrate amount on locomotion and clinical lameness in dairy cattle. Anim. Prod. 1988a, 47, 185-190.

Manson FJ, Leaver JD: The influence of dietary protein intake and of hoof trimming on lameness in dairy cattle. Anim. Prod. 1988b, 47, 191-199.

Manson FJ, Merritt JB: Feeding factors associated with lameness: A preliminary report from an epidemiological survey. Proc. VIth Int. Symp. Dis. Ruminant Digit. Liverpool, England, 1990, 96101.

Mills LL, Leach DH, Smart ME, Greenough PR: A system for the recording of clinical data as an aid in the diagnosis of bovine digital disease. Can. vet. J. 1986, 27, 293-300.
Nilsson SA: Clinical, morphological and experimental studies of laminitis in cattle. Acta vet. scand. 1963, 4, Suppl. 1.

Peterse DJ: Subclinical laminitis in the Netherlands. Proc. IInd Int. Symp. Dis. Ruminant Digit. Skara, Sweden, 1978, 84-86.

Peterse DJ: Judgement of bovine claws by the occurrence of sole lesions. Thesis, Utrecht, the Netherlands, 1980.

Philipot J-M, Pluvinage P, Cimarosti I, Luquet F: On indicators of laminitis and heelhorn erosion in dairy cattle: a research based on the observation of digital lesions, in the course of an ecopathological survey. Proc. VIth Int. Symp. Dis. Ruminant Digit., Liverpool, England, 1990, 184-198.

Prentice DE: Growth and wear rates of hoof-horn in Ayrshire cattle. Res. vet. Sci. 1973, 14, 285-290.

SAS Institute Inc: $\mathrm{SAS}^{\circledR}$ procedures guide for personal computers, Version 6 ed. Cary, NC, USA, 1987.

Smedegaard HH: Contusion of the sole in cattle. The veterinarian 1964, 2, 119-139.

Thysen I, Buchwald E, Smedegaard HH: Skader og sygdomme in malkekoens klove. (Lesions and diseases of the bovine claw). 515 Beretning fra Statens husdyrbrugsfors $\emptyset$, København, Denmark, 1981, 49-72.

Vermunt JJ: Lesions and structural characteristics of the claws of dairy heifers in two management systems. Thesis, Saskatoon, Canada, 1990.

Weaver $A D$ : The prevention of laminitis in dairy cattle. Bovine Practitioner 1979, 14, 70-72.

\section{Sammanfattning}

Fotometrisk metod för registrering av klöv-sjukdomar med särskild inriktning på blödningar $i$ sulhornet.

Efter rengöring och verkning fotograferas klövarna på ett standardiserat sätt. Diabilderna i färg projiceras på en duk och sulblödningar som indikerar Pododermatitis aseptica diffusa samt lesioner av Dermatitis interdigitalis och Erosio ungulae bedöms med hänsyn till grad och utbredning av skadan av 2 personer som inte känner djurets identitet. Vid en test av repeterbarheten av sulblödningar i fram-, bak- och samtliga klövar varierade korrelationskoefficienten mellan 0,78 och 0,88 .

(Received March 18, 1993; accepted March 23, 1993).

Reprints may be requested from: C. Bergsten, Experimental Station, Veterinary Institute, P.O.Box 234, S-532 23 Skara, Sweden. 